\title{
Simulation of the insulating properties of two-layer material
}

\author{
I.F.Dadashov, A.A.Kireev, I.K.Kirichenko, \\ A.A.Kovalev, A.Ya.Sharshanov \\ National University of Civil Protection of Ukraine, 94 Chernyshevska
Str., 61028 Kharkiv, Ukraine
}

Received May 4, 2018

\begin{abstract}
Mathematical simulation of the process of diffusion of liquid vapors through a binary layer consisting of a light granular material and a layer of gel applied on its surface is shown. Using the proposed model the coefficient of octane evaporation rate reduction on the onset of the stationary mode was determined, and the time for reaching this mode was estimated. For a gel layer with thickness of $2 \mathrm{~mm}$ and a layer of foam glass with thickness of $5 \mathrm{~cm}$, the evaporation rate of octane is reduced by more than 100 times compared with the evaporation rate from the free surface of the liquid. Two-layer insulating materials are proposed to use for elimination of emergencies associated with the spill of toxic and flammable liquids, as well as for extinguishing fires involving flammable liquids.

Keywords: mathematical simulation, vapors of flammable liquids, diffusion, two-layer material, porous coating, granulated foam glass, gel layer, flow reduction ratio.

Проведено математическое моделирование процесса диффузии паров жидкостей сквозь бинарный слой, состоящий из лёгкого гранулированного материала и нанесенного на его поверхность слоя геля. На основании предложенной модели проведено определение коэффициента уменьшения скорости испарения октана при наступлении стационарного режима и оценено время выхода на этот режим. Для толщины слоя геля 2 мм и толщины слоя пеностекла 5 см скорость испарения октана уменьшается более, чем в 100 раз по сравнению со скоростью испарения со свободной поверхности жидкости. Предложено использовать двухслойные изолирующие материалы для ликвидации чрезвычайных ситуаций, связанных с разливом токсичных и горючих жидкостей, а также при тушении пожаров с участием горючих жидкостей.
\end{abstract}

Моделювання ізолюючих властивостей двошарового матеріалу сформованого на поверхні рідини. І.Ф.Дадашов, О.О.Кірєєв, І.К.Кириченко, О.О.Ковальов, А.Я.Шаршанов.

Проведено математичне моделювання процесу дифузії пари рідин крізь бінарний шар, що складається з легкого гранульованого матеріалу i нанесеного на його поверхню шару гелю. На підставі запропонованої моделі проведено визначення коефіцієнта зменшення швидкості випаровування октану при досягненні стаціонарного режиму i оцінено час виходу на цей режим. Для товщини шару гелю 2 мм і товщини шару піноскла 5 см швидкість випаровування октану зменшується більше, ніж у 100 разів у порівнянні зі швидкістю випаровування з вільної поверхні рідини. Запропоновано використовувати двошарові ізолюючі матеріали для ліквідації надзвичайних ситуацій пов'язаних з розливом токсичних і горючих рідин, а також при гасінні пожеж за участю горючих рідин. 


\section{Introduction}

Prevention or slowing down the evaporation of liquids is a necessary requirement during their handling.

In all, the reduction of liquid evaporation requires formation of a layer on its surface possessing high insulating properties. Air-mechanical foam is almost the only insulating means used in emergency situations.

However, the critical parameters of currently most effective film-forming agents are their environmental characteristics [1-3]. They turned out to be 150 times more toxic than the "biologically harsh" PO-6K foaming agent and 2500 times more stable to biodegradation in the environment [4]. For elimination of the large part of the drawbacks of air-mechanical foams described above, gel-like layers were proposed to be applied as an insulating material formed on the light non-combustible carriers [5, 6]. To obtain a gel layer, gel-forming fire extinguishing systems were used [7] in the form of two separately stored and separately/simultaneously supplied solutions. The components of the solution are specially selected in order to provide a non-flowing gel layer as a result of their mixture.

Loss of fluidity of this gel-forming system is determined by the formation of a continuous macromolecular network, which acts as a framework. In the voids of the network molecules of substances with low molecular weight are situated. In the case of mixing calcium chloride and sodium polysilicate solutions mainly amorphous micelles of calcium polysilicate are formed, which quickly form a framework by the condensation mechanism [8].

Let us consider the phase composition of the gel using $\mathrm{CaCl}_{2}(10 \%)+\mathrm{Na}_{2} \mathrm{O} \cdot 2.7 \mathrm{SiO}_{2}(10 \%)$ gel-forming system. For the chosen gelforming system main reaction is:

$$
\begin{aligned}
& \mathrm{CaCl}_{2}+\mathrm{Na}_{2} \mathrm{O} \cdot 2.7 \mathrm{SiO}_{2}= \\
= & \mathrm{CaO} \cdot 2.7 \mathrm{SiO}_{2} \downarrow+2 \mathrm{NaCl} .
\end{aligned}
$$

At the same time some amount of silica gel can be formed [8]. Using the reaction stoichiometry one can calculate the mass fraction of the gel framework, sodium chloride and calcium chloride, which is in excess compared to liquid glass. The corresponding data are presented in Table.

Using these data, one can conclude that the solid phase from which the gel framework is built is only $4.7 \%$ by mass or $1.7 \%$ by volume (the density of calcium polysilicates is $\left.\sim 2.8 \mathrm{~g} / \mathrm{cm}^{3}\right)$. The insignificant content of the solid phase in the composition of the gel indicates that the diffusion coefficients of substances dissolved in the gel should not sufficiently differ from the corresponding values of aqueous solutions [9]. Small concentrations of calcium and sodium chlorides in the liquid phase also should not lead to significant change in the diffusion coefficient in the gel-like layer. So, the insulating properties of the gel will be close to the insulating properties of the water layer of the same thickness.

However, the direct use of the gel as an insulating coating for organic liquids is impossible, since its density is higher than the density of most liquids. For providing the buoyancy of the gel layer in flammable liquids lightweight non-combustible carrier in the form of granulated foam glass was proposed [6]. Preliminary experiments have shown that foam glass-gel two-layer material remains stable on the surfaces of liquid hydrocarbons and their halogen derivatives, a number of alcohols, amines and nitro compounds for several days.

So, the proposed technology for isolation of liquids consists of two stages. The first stage is the uniform deposition of a layer of a light carrier i.e. granulated foam glass on the surface of the liquid. The second stage consists in the deposition of the components of gel-forming system on the layer of foam glass. As a result, the resulting light carrier-gel double layer provides isolation of the space above the gel layer from the penetration of the vapors from the liquids.

Earlier $[10,11]$, the high insulating properties of the gel-like layer of $\mathrm{CaCl}_{2}(10 \%)+\mathrm{Na}_{2} \mathrm{O} \cdot 2.7 \mathrm{SiO}_{2}(10 \%)$ system in relation to vapors of organic liquids were

Table. The composition of the gel formed from $\mathrm{CaCl}_{2}(10 \%)+\mathrm{Na}_{2} \mathrm{O} \cdot 2,7 \mathrm{SiO}_{2}(10 \%)$ gel-forming system

\begin{tabular}{|c|c|c|c|c||}
\hline & $\mathrm{CaCl}_{2}$ & $\mathrm{CaO} \cdot 2,7 \mathrm{SiO}_{2}$ & $\mathrm{NaCl}$ & $\mathrm{H}_{2} \mathrm{O}$ \\
\hline State & liquid & solid & liquid & liquid \\
\hline Content, wt.\% & 2.6 & 4.7 & 2.7 & 90 \\
\hline
\end{tabular}


shown. The factor of evaporation slowing down for hydrocarbons of continuous gel layer with a thickness of $(1-2) \mathrm{mm}$ is $(30 \pm 5)$. It was also found that the layer of foam glass plays a sufficient part in the slowing the evaporation of liquids [12]. In this way, a layer of foam glass with a thickness of $10 \mathrm{~cm}$ reduces the rate of evaporation of gasoline in 5 times.

In [13], the effect of the thickness of the foam glass layer, and in [14] the effect of the thickness of the gel layer on the rate of evaporation of liquids was simulated. In $[15,16]$, solutions of similar problems for other objects were analyzed. However, no simulation of the combined effect of the foam glass layer and the gel layer on the evaporation of flammable liquids is present in the literature up to now.

This paper is dedicated to the simulation of the processes of liquid vapors penetration through a two-layer material consisting of a light granular carrier, on the surface of which a gel layer is deposited. The task was to determine the characteristics of this process in a stationary mode and to estimate the time for entering this mode.

\section{Methods}

The scheme of the problem is shown in Fig. The shaded area corresponds to the liquid over which the layer of foam glass granules floats. The thickness of this layer is indicated as $h_{g r}$. The part of the foam glass layer not immersed into the liquid has a thickness $h$. The layer of granules is separated from the external (air) environment by a layer of gel with thickness $h_{g}$. A transition layer with thickness $\delta$ within which a concentration of liquid vapors $c\left(\mathrm{~mol} \cdot \mathrm{m}^{-3}\right)$ changes from its value at the surface of the gel $c_{a}$ to the values in external environment $c_{a 0}$ is located above the helium layer. In the diagram the subscripts correspond to the location: "a" - air environment, "g" - helium layer, "gr" — voids of the granular layer; the indices " 1 " and " 2 " correspond to the lower and upper parts of corresponding layer.

It should be noted that value of $h$ is closely related to the thicknesses of the layers $h_{g r}$ and $h_{g}$, by

$$
h=h_{g r} \cdot\left(1-\frac{\rho_{g r}}{\rho_{f}}\right)-h_{g} \frac{\rho_{g}}{\left(1-r_{V}\right) \cdot \rho_{f}},
$$

where $\rho_{g r}, \rho_{g}$ and $\rho_{f}$ are the densities of the materials of the granules, gel and liquid,

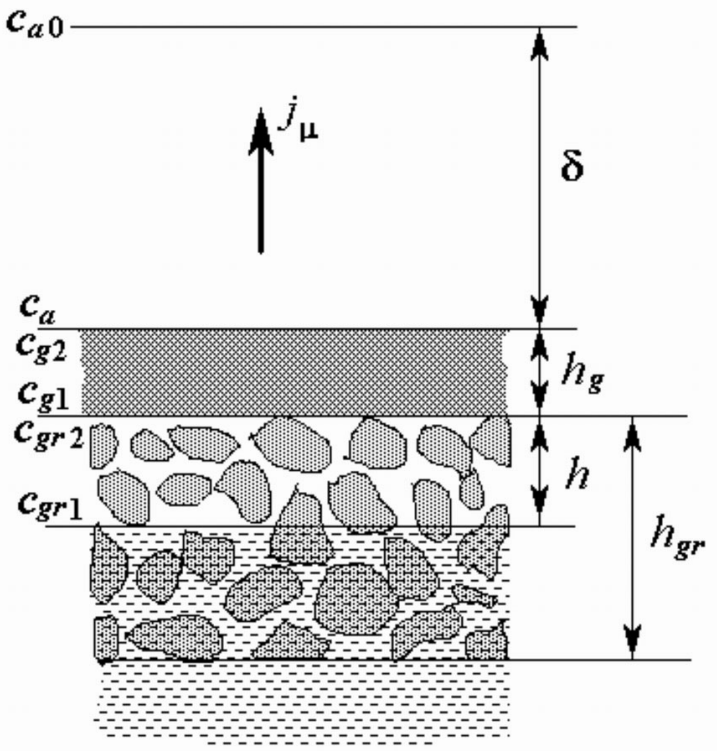

Fig. Spatial scheme of the problem of fuel vapor transfer through layers of granular material and gel.

respectively, $\mathrm{kg} \cdot \mathrm{m}^{-3} ; r_{V}-$ volume fraction of voids in granular material.

The transfer of the vapors through the voids of the granular material is provided by diffusion. The corresponding equation of stationary mass transfer through this layer is:

$$
j_{\mu . g r}=\frac{D_{g r}}{h}\left(c_{g r 1}-c_{g r 2}\right), \mathrm{mol} \cdot \mathrm{m}^{-2} \cdot \mathrm{s}^{-1} \text {, }
$$

where $j_{\mu . g r}$ is a density of the molar vapor flow through the layer of granules, per unit area of the layer, mol.m $\mathrm{m}^{-2} \cdot \mathrm{s}^{-1} ; D_{g r}$ is vapor diffusion coefficient through a layer of granules, $\mathrm{m}^{-2} \cdot \mathrm{s}^{-1} ; c_{g r 1}$ and $c_{g r 2}$ are vapor concentrations in the voids of the granulated layer at its lower and upper boundaries (Fig.)

The sizes of the voids between the granules are large compared with the mean free path of gas molecules, so

$$
c_{g r 1}=c_{s}
$$

where $c_{s}-$ equilibrium concentration of vapor at the surface of liquid, $\mathrm{mol} \cdot \mathrm{m}^{-3}$.

The diffusion coefficient of vapor in the air through a layer of granules $D_{g r}$ is proportional to the diffusion coefficient of vapor in air without granules $D_{a}, \mathrm{~m}^{-2} \cdot \mathrm{s}^{-1}$. In [17] one of the authors has shown that: 


$$
D_{g r} \leq D_{a} \cdot\left(\frac{h}{l_{m}}\right)^{2} \cdot r_{V},
$$

where $r_{V}$ is a volume fraction of voids for a layer consisting of granules through which the vapors of the liquid moves, $l_{m}-$ the average length of the streamtube between the surfaces of the layer. It should be noted that generatrices of the streamtubes are parallel to the flux (density vectors of the diffusing vapors of the liquid, and the ratio $\left(h / l_{m}\right)$ is practically independent of layer thickness $h$.

Negligibly low fluidity of the gel leads to exclusively diffusive character of the transfer of fuel vapors through the gel. The corresponding stationary mass transfer equation in the helium layer is:

$$
j_{\mu . g}=\frac{D_{g}}{h_{g}}\left(c_{g 1}-c_{g 2}\right), \mathrm{mol} \cdot \mathrm{m}^{-2} \cdot \mathrm{s}^{-1},
$$

where $j_{\mu . g}$ is the surface density of the molar flow of fuel vapor through the gel layer, mol.m $\mathrm{m}^{-2} \cdot \mathrm{s}^{-1} ; D_{g}$ is the vapor diffusion coefficient in the gel, $\mathrm{m}^{2} \cdot \mathrm{s}^{-1} ; c_{g 1}$ and $c_{g 2}$ is vapor concentration in the gel layer near its corresponding surfaces, $\mathrm{mol} \cdot \mathrm{m}^{-3}$ (Fig.).

At the boundary between voids of the granulated material and helium layer, the phase equilibrium condition is fulfilled, and therefore, the concentrations of vapors at this boundary are related by:

$$
c_{g 1}=\frac{c_{g r 2}}{k_{1}}
$$

where $k_{1}$ is a distribution coefficient.

A similar phase equilibrium condition connects the concentrations of vapors at the air-gel boundary:

$$
c_{g 2}=\frac{c_{a}}{k_{2}}
$$

$\mathrm{mol} \cdot \mathrm{m}^{-3}$ (Fig.); $k_{2}$ is the value of the distribution coefficient at the corresponding boundary. Note that the distribution coefficient is a function of temperature, and so, for isothermal diffusion $k_{1}=k_{2}=k$.

The surface density of the molar vapor flow in air $j_{\mu . a}$ satisfies the mass transfer equation [17]:

$$
j_{\mu . a}=\beta \cdot\left(c_{a}-c_{a 0}\right), \mathrm{mol} \cdot \mathrm{m}^{-2} \cdot \mathrm{s}^{-1},
$$

where $c_{a 0}$ is the concentration of the vapors in the air (in the gas phase core) at dis- tances exceeding the width of the transition region $\delta$ (Fig. 1); $\beta$ is the coefficient of mass transfer of vapors in the air, $\mathrm{m} \cdot \mathrm{s}^{-1}$.

Coefficient $\beta$ is connected with the width of the transition region $\delta$ by:

$$
\beta=\frac{D_{a}}{\delta},
$$

where $D_{a}$ - vapor diffusion coefficient in air, $\mathrm{m}^{2} \cdot \mathrm{s}^{-1}$. On the other hand, the width of the transition region can be estimated using the ratio:

$$
\delta=\frac{l}{N u_{D}}
$$

where $l$ - characteristic spatial size of the problem, m; $N u_{D}$ is the Nusselt number (or Sherwood number $S h$ ).

It should be noted that $j_{\mu . g r} \geq j_{\mu . g} \geq j_{\mu . a}$ and equality of flows can be observed when a stationary stage of the mass transfer process is completely achieved. In this mode, the solution of the system of equations (1) - (7) allows to obtain the resulting maximum possible value of the surface density of the molar flow of vapors. $j_{\mu . g r}=j_{\mu . g}$ $=j_{\mu . a}=j_{\mu}$, which in the case of isothermal diffusion is given by:

$$
j_{\mu}\left(h_{g}, h\right)=\frac{\beta \cdot\left(c_{s} \cdot \frac{k_{2}}{k_{1}}-c_{a 0}\right)}{1+\beta \cdot k_{2} \cdot \frac{h_{g}}{D_{g}}+\beta \cdot \frac{k_{2}}{k_{1}} \cdot \frac{h}{D_{g r}}},
$$

Relation (10), taking into account (8), can be re-written as:

$$
=\frac{j_{\mu}\left(h_{g}, h\right)=}{1+k_{2} \cdot \frac{h_{g}}{\delta} \cdot \frac{D_{a}}{D_{g}}+\frac{k_{2}}{k_{1}} \cdot \frac{h}{\delta} \cdot \frac{D_{a}}{D_{g r}}} \approx \frac{j_{\mu .0}}{K},
$$

where

$$
j_{\mu .0}=\beta \cdot\left(c_{s}-c_{a 0}\right), \mathrm{mol} \cdot \mathrm{m}^{-2} \cdot \mathrm{s}^{-1},
$$

denotes the density of the flow of liquid evaporating from the free surface, and the parameter $K$ is given by:

$$
K=1+k_{2} \cdot \frac{h_{g}}{\delta} \cdot \frac{D_{a}}{D_{g}}+\frac{k_{2}}{k_{1}} \cdot \frac{h}{\delta} \cdot \frac{D_{a}}{D_{g r}} .
$$

Using relations (7), (10) and (13), it is possible to determine the vapor concentra- 
tion directly above the surface of the gel layer.

$$
c_{a}=\frac{j_{\mu}}{\beta}+c_{a 0}=\frac{c_{s} \cdot \frac{k_{2}}{k_{1}}+(K-1) \cdot c_{a 0}}{K} \approx \frac{c_{s}}{K} .
$$

From (11) and (14), it follows that the deposition of the layers of granular material and gel onto the surface of the liquid reduces the stationary flow of fuel vapor and its concentration at the entrance to the air environment in $K$ times.

Flow (10) is achieved in a stationary mode which can be achieved during $\tau_{s t}$, exceeding the sum of the characteristic diffusion times of vapors through the layers of granular material $\tau_{g r}$ and gel $\tau_{g}$ :

$$
\begin{gathered}
\tau_{r g}=\frac{h^{2}}{D_{g r}}, \\
\tau_{g}=\frac{h_{g}^{2}}{D_{g}} .
\end{gathered}
$$

We have estimated numerically the values of $K, \tau_{g r}$ and $\tau_{g}$ taking into account the fact that the properties of gel considered in our problem differ insignificantly from the corresponding properties of water [9]. As the diffusing substance we took octane, and our estimation corresponds to the temperature of $20^{\circ} \mathrm{C}$.

The value of distribution coefficient $k=$ $k_{2} \approx k_{1}$, can be obtained using (6), with $c_{a}$ corresponding to maximum possible value of $c_{s}$. For estimation of liquid concentration in water $c_{g 2}$ we used the reference value of the solubility coefficient of octane in water $k_{m}$ [19], while for estimation of the concentration of saturated octane vapors $c_{s}$ we used empirical Antoine equation:

$$
\lg p_{s}=A-\frac{B}{t+C},
$$

where $A, B, C$ are constants, and $t$ is a temperature in Celsius degrees using which a pressure of saturated vapors $p_{s}, \mathrm{kPa}$ can be found, and which, in turn, gives the concentration using the ideal gas law.

In this way, for octane $k_{m}=1.5 \cdot 10^{-5}$ grams of octane per gram of water. This solubility corresponds to the concentration of octane in water

$$
c_{g 2}=\frac{k_{m} \cdot \rho_{w}}{\mu}=0.13 \mathrm{~mol} \cdot \mathrm{m}^{-3} .
$$

In (18) the low value of solubility was used $\left(k_{m}<<1\right)$; density of water was taken as $\rho_{w}=1000 \mathrm{~kg} \cdot \mathrm{m}^{-3}$ and molar mass of octane $\mu=114 \cdot 10^{-3} \mathrm{~kg} \cdot \mathrm{mol}^{-3}$.

For octane the constants (17) are $A=$ 6.094, $B=1379.6, C=211.9$, corresponding at $t=20^{\circ} \mathrm{C}$ to the pressure of saturated vapors $p_{s}=1.40 \mathrm{kPa}$. For ideal gas this pressure gives the concentration:

$$
c_{s}=\frac{p_{s}}{R \cdot T}=0.57 \mathrm{~mol} \cdot \mathrm{m}^{-3},
$$

where $R=8.314 \mathrm{~J} \cdot \mathrm{mol}^{-1} \cdot \mathrm{K}^{-1}$ is the ideal gas constant; $T$ is absolute temperature of vapors, $\mathrm{K}$.

Using the results of (18), (19) we obtain the estimation of octane distribution coefficient at $20^{\circ} \mathrm{C}$ :

$$
k=\frac{c_{s}}{c_{g 2}}=4.4 .
$$

Diffusion coefficient $D_{g}$ can be estimated using the formula for the diffusion coefficient of a Brownian particle (octane molecule) in liquid (water):

$$
D_{g}=\frac{k_{B} \cdot T}{6 \cdot \pi \cdot \rho_{w} \cdot v_{w} \cdot r_{0}}, \mathrm{~m}^{2} \cdot \mathrm{s}^{-1},
$$

where $k_{B}=1.38 \cdot 10^{-23} \mathrm{~J} \cdot \mathrm{K}^{-1}$ is Boltzmann constant; $v_{w}$ is the coefficient of kinematic viscosity of water, $\mathrm{m}^{2} \cdot \mathrm{s}^{-1} ; r_{0}$ is an effective radius of a diffusing particle, $m$. Taking into account that at $20^{\circ} \mathrm{C}$ reference value of $v_{w}=1.005 \cdot 10^{-6} \mathrm{~m}^{2} \cdot \mathrm{s}^{-1}$, while estimation gives $r_{0}=3.8 \cdot 10^{-10} \mathrm{~m}$, from (21) we get $D_{g}$ $=5.6 \cdot 10^{-10} \mathrm{~m}^{2} \cdot \mathrm{s}^{-1}$.

According to (16) the characteristic diffusion time in the helium layer is:

$$
\tau_{g}=1.8 \cdot 10^{3} \cdot h_{g}^{2}, \mathrm{~s} .
$$

(in (22) the thickness of helium layer $h$ is taken in $\mathrm{mm}$ ).

The diffusion coefficient of octane vapors in the air can be determined using the empirical ratio:

$$
D_{a}=D_{a .0} \cdot\left(\frac{T}{T_{0}}\right)^{2}, \mathrm{~m}^{2} \cdot \mathrm{s}^{-1},
$$

where $T_{0}=273 \mathrm{~K} ; D_{a .0}$ is the value of diffusion coefficient at $T_{0}$. For octane the reference value $D_{a .0}=5.5 \cdot 10^{-6}, \mathrm{~m}^{2} \cdot \mathrm{s}^{-1}$, so at $20^{\circ} \mathrm{C}$ we get $D_{a}=6.3 \cdot 10^{-6} \mathrm{~m}^{2} \cdot \mathrm{s}^{-1}$. 
For estimation of $D_{g r}$ we use (3), taken $\left(h / l_{m}\right)^{2}=0.5$ and $r_{V}=0.25$. As a result we get $D_{g r} \approx 0.8 \cdot 10^{-6} \mathrm{~m}^{2} \cdot \mathrm{s}^{-1}$.

This value of $D_{g r}$ corresponds (according to (15)) to the characteristic time for achieving stationary stage:

$$
\tau_{g r}=1.25 \cdot 10^{2} \cdot h^{2}, \mathrm{~s}
$$

(in (24) the thickness of the layer of granulated material $h$ is taken in centimeters).

Inserting the obtained values of $k=$ $k_{2} \approx k_{1}, D_{g}, D_{g r}, D_{a}$ to (13), with (9), we get an estimate of the minimum value of the coefficient of flow reduction by layers of granular material and gel:

$$
\begin{aligned}
K & =1+5.0 \cdot 10^{4} \cdot \frac{h_{g}}{\delta}+\frac{h}{\delta} \cdot \frac{1}{r_{v}} \cdot\left(\frac{l_{m}}{h}\right)^{2}= \\
& =1+N u_{D} \cdot\left(5.0 \cdot 10^{4} \cdot \frac{h_{g}}{l}+8 \cdot \frac{h}{l}\right) .
\end{aligned}
$$

Taking into account that minimum value of $N u_{D} \sim 1$, from (25) we find that for typical surface sizes of $l \sim 1 \mathrm{~m}$, the attenuating effect of the helium layer is high already at the thickness of $\sim 0.1 \mathrm{~mm}$ even in the stationary mode. Similar attenuating effect is observed for values of $h$ higher by more than 4 orders of magnitude.

In previous experimental studies $[13,14]$ the minimum thickness of a continuous gellike layer deposited on a horizontal surface was shown to be at least $1 \mathrm{~mm}$. In [15], it was shown that the properties of foam glass can be used with the highest efficiency when it is more than $5 \mathrm{~cm}$ thick. This value can be taken as minimal one. The calculated value of the attenuation coefficient of the octane vapor flow for such thicknesses of the insulating layers according to equation (25) will be 51.4. When the thickness of the gel layer is $2 \mathrm{~mm}$, the value of $K$ will be 101.4. Such properties of insulating twolayer materials makes it appropriate to use them in case of emergencies associated with the spill of toxic and flammable liquids, as well as at extinguishing fires involving flammable liquids.

\section{Conclusions}

In the paper the mathematical simulation of the processes of evaporation of vapors of liquids through a double insulating layer consisting of a gel deposited on the surface of foam glass. The coefficient of attenuation of the evaporation rate of octane at the onset of the stationary mode was estimated. For a gel layer with thickness of $2 \mathrm{~mm}$ and a layer of foam glass with thickness of $5 \mathrm{~cm}$, the evaporation rate of octane is reduced by more than 100 times compared with the evaporation rate from the free surface of the liquid. Two-layer insulating materials are proposed for elimination of emergencies associated with the spill of toxic and flammable liquids, as well as for extinguishing fires involving flammable liquids.

\section{References}

1. R.C.Buck, J.Franklin, U.Berger et al., Integrated Environ. Assess. Manage., 7, 513 (2012).

2. J.W.Martin, M.M.Smithwick, B.M.Braune et al., Environ Sci. Technol., 38, 373 (2004).

3. K.Kannan, S.Corsolini, J.Falandysz et al., Environ Sci. Technol., 38, 89 (2004).

4. V.V.Bocharov, Pozharovzryvobezopasnost', 22, 75 (2013).

5. RF Patent 2264242 (2005).

6. I.F.Dadashov, Keramika: Nauka i Zhizn', 2, 44 (2016).

7. Yu.A.Abramov, A.A.Kireev, Gelling Fire Extinguishing and Flame Retardant Means of Increased Efficiency in Relation to Class A Fires, NUCDU, Kharkiv (2015).

8. R.Ayler, The Chemistry of Silica, Wiley Interscience, New York (1979).

9. D.A.Friedrichsberg, Course of Colloid Chemistry, Khimiya, Leningrad (1974) [in Russian].

10. I.F.Dadashov, Problemi Tsyvil'nogo Zakhistu, 25, 22 (2017).

11. I.F.Dadashov, A.A.Kireev, A.Ya.Sharshanov et al, Problemy Tsyvil'nogo Zakhistu, 26, 43 (2017).

12. I.F.Dadashov, Problemy Pozharnoy Bezopasnosti, 42, 27 (2017).

13. I.F.Dadashov, A.A.Kireev, A.Ya.Sharshanov, Problemy Pozharnoy Bezopasnosti, 42, 53 (2017).

14. I.F.Dadashov, A.A.Kireev, A.Ya.Sharshanov et al., Problemy Pozharnoy Bezopasnosti, 40, 78 (2016).

15. G.I.Barenblatt, V.M.Yentov, V.M.Ryzhik, Movement of Liquids and Gases in Natural Formations, Nedra, Moscow (1984) [in Russian].

16. G.I.Barenblatt, V.M.Yentov, V.M.Ryzhik, Theory of Non-stationary Filtration of Liquid and Gas, Nedra, Moscow (1972) [in Russian].

17. A.Ya.Sharshanov, Problemy Pozharnoy Bezopasnosti, 41, 206 (2017).

18. D.A.Frank-Kamenetskiy, Diffusion and Heat Transfer in Chemical Kinetics, Nauka, Moscow (1967) [in Russian].

19. B.N.Nikolsky, Chemist Handbook, Goskhimizdat, Leningrad (1963) [in Russian]. 